\title{
Comparison of Environmental Impacts of Deep-sea Tailings Placement Versus On-land Disposal
}

\author{
Y. T. John Kwong $(\mathbb{D} \cdot$ Simon C. Apte • Gert Asmund • \\ Michael D. E. Haywood • Elisabetta B. Morello
}

Received: 26 August 2019/Accepted: 17 November 2019/Published online: 2 December 2019

(C) The Author(s) 2019

\begin{abstract}
With increasing metal prices and declining ore grades, new mines are getting larger and mine waste disposal and management have become more difficult, particularly from an environmental perspective. While technologies keep on improving, the available space for terrestrial mine waste disposal is limited. Thus, several coastal countries still consider deep-sea tailings placement (DSTP) as a viable option. This brief review compares the environmental impacts of DSTP versus on-land disposal and suggests several factors to consider in selecting the most suitable options for mine waste disposal.
\end{abstract}

Keywords DSTP - Tailings disposal - Environmental impacts $\cdot$ Acceptability $\cdot$ Geoenvironmental model

\author{
Y. T. J. Kwong $(\bowtie)$ \\ CanmetMINING, Natural Resources Canada, 555 Booth Street, \\ Ottawa, Ontario K1A 0G1, Canada \\ e-mail: john.kwong@canada.ca \\ S. C. Apte \\ CSIRO Land and Water, Lucas Heights, NSW, Australia \\ G. Asmund \\ Aarhus University, Aarhus, Denmark \\ M. D. E. Haywood \\ CSIRO Oceans and Atmosphere, QLD, Brisbane, Australia
}

E. B. Morello

CNR-National Research Council of Italy, ISMR - Marine

Sciences Institute, Rome, Italy

\section{Introduction}

With increasing metal prices (e.g., US \$25/ounce of gold in the 1960 s to $\geq$ US $\$ 1400$ /ounce currently) and declining reserves, ore bodies mined today are of lower grade than in the past. This leads to increased volumes of mine wastes (tailings and waste rock) being produced at operating mines. On-land (aerial and subaqueous) and submarine disposals are the major options for managing tailings. Unlike in the past, in-lake tailings disposal is seldom used today. Similarly, tailings disposal into rivers is not allowed globally (GESAMP 2016), except for three operating mines in Papua New Guinea and one in Indonesia. Currently there are about 2500 industrialsized mines worldwide and $99.3 \%$ of them dispose their tailings on-land (Vogt 2014). This gives rise to the existence of at least 3500 mine tailings dams and/or impoundments (Vogt 2013). Since construction of the first storage dam, there have been 141 significant recorded failures. Vogt (2013) cited 138 dam failures; in addition, failures occurred in 2014 at the Mount Polley Mine (Province of British Columbia, Canada), in 2015 at the Samarco Mine, and in January 2019 at the Vale's Feijao iron ore mine, both in Brazil. The environmental impacts of the last two dam failures are still under investigation.

In 2015, there were 16 mines worldwide using submarine tailings disposal (GESAMP 2016) as an alternative to land-based tailings storage. This paper compares submarine versus on-land tailings disposal from the perspective of environmental impacts. A brief history of submarine tailings disposal (STD) and the development 
of deep sea tailings placement (DSTP) is followed by a description of changing regulations to enforce environmentally safer tailings disposal practices on land and at sea. After a brief discussion on the advantages and disadvantages of both techniques, the use of geoenvironmental ore deposit models (Plumlee and Logsdon 1999; Seal II and Folsey 2002; Kwong 2003) to make informed decisions is considered.

\section{History of Submarine Tailings Disposal}

In the early days, mining operations were largely unplanned with tailings and other waste materials directly discharged into the sea as a matter of convenience, for example, at Howe Sound (Britannia Mine), British Columbia, Canada (Drysdale 1990; Syvitski and Macdonald 1982); Tilt Cove, Newfoundland, Canada (Kwong and Hynes 2003); Portman Bay (Roberto Mine), and Cartagena, Spain (Pena et al. 2013). This often led to contamination of the nearshore environment and adverse impacts on local biota (Castilla and Nealler 1978; Ellis and Hoover 1990). Starting in the early 1970s, pipelines and engineered systems came into practice for marine tailings disposal. Over time, design modifications to both the tailings outfall and the final tailings deposition basin have located them at progressively greater depths to minimize environmental impacts (Ellis and Ellis 1994).

The large-scale practice of engineered STD started in 1971 at the Island Copper Mine in Vancouver Island, Canada (Ellis et al. 1995; Poling 2002), and the Atlas Copper Mine on Cebu Island, Philippines (Ganguli et al. 2002). In Tasmania, from 1973 to 1977, the Pasminco Metals EZ Company dumped 170,000 tonnes per annum of waste (jarosite) from their refinery process offshore of Hobart at $2000 \mathrm{~m}$ depth (Bradford et al. 1999). In addition, two other closed STD operations, the Kitsault molybdenum mine (British Columbia, Canada) and the Black Angel Mine (Greenland), have been widely discussed in the literature. While the Island Copper and Kitsault mines did not seem to have significant long-term ecological impacts (e.g., Burd 2002), the adopted STD system at the Black Angel Mine caused contamination of the receiving fjord (Asmund et al. 1991; Larsen et al. 2001; Loring and Asmund 1989; Perner et al. 2010). Most STD operations that started in the early 1970s are now closed.
Overall, as pointed out by Vogt (2013), submarine tailings disposal is limited to a small number of mines and types of operation. These include metals (such as copper, gold, and silver), iron, rutile $\left(\mathrm{TiO}_{2}\right)$, graphite, and pigments. Coal, uranium, and diamond mines do not discharge tailings into the ocean.

The regulatory landscape has also evolved along with the development of more sophisticated means of marine tailings disposal. Since the beginning of mining, the produced mine waste has been placed as close as possible to the mine. For nearshore mines, often tailings were disposed into the ocean until establishment of local and/ or national regulations that dictate how tailings should be disposed or stored. Examples of ocean disposal in Canada prior to law enforcement include the Tilt Cove gold mine in northeastern Newfoundland (Kwong and Hynes 2003) and the Britannia Mine near Vancouver, British Columbia (Ellis and Hoover 1990; EVS Environmental Consultants 1997). Due to their small size and particular oceanographic settings, the environmental effects were not significant but this might not be true for larger mines.

In North America, STD was legal in the early 1970s. Operations approved for STD in Canada included the Island Copper Mine and Kitsault molybdenum mine in British Columbia, both of which deposited their tailings in adjacent fjords. Due primarily to the subaerially confined locations, the environmental effects were not particularly significant (Burd 2002; Burd et al. 2000; Ellis 2008). Smaller mines in Southern British Columbia also discharged their tailings into the nearby sea but at much shallower depths. With less geographic restriction, the tailings spread and affected biota. Consequently, such operations became unpopular in the 1980s and since then, STD has become illegal. These examples led to many publications in the 1990s (e.g., Ellis and Poling 1995) that emphasized the need to dispose tailings at a greater depth.

In South America, there are currently no STD regulations largely due to the lack of big mines near the ocean, with the exception of an iron mine (Huasco) in Chile. However, significant environmental effects of STD at some South American coastal mines have been reported (e.g., Vogt 2013; Dold 2006; Dold 2014; Lee et al. 2002). Consequently, Chile is now in the process of developing regulations on STD to improve the situation, and Peru is interested in undertaking similar actions (GESAMP 2016). 
In Europe, out of fifty-three countries participating in the September 2016 meeting of the Union for Conservation of Nature (IUCN), only Norway and Turkey voted against an international ban on marine mine waste dumping. In Norway, three metal mines currently have permission to dispose tailings into fjords (Vogt 2013). The first site is a diminishing iron mine near the Norway-Russia border with tailings that practically fill up a fjord. The second one is a planned copper mine on the Barents Sea coast expected to deposit two million tonnes of tailings annually in the fjord. The third site is on Norway's west coast, a rutile ore mine planning to dump tailings in deep water. Elsewhere, at the Cayeli Bakir copper mine in Turkey, tailings are essentially disposed into a deep deoxygenated zone of the Black Sea (Berkun 2005), while in Greenland mines that used to discharge tailings into shallow fjords (e.g., the Black Angel Mine (Berkun 2005) are no longer in operation.

In the Pacific Ocean, particularly closer to the equator, several mines in Indonesia, Papua New Guinea, and the Philippines used to dispose tailings into the shallow sea but currently this practice has stopped (Morello et al. 2016). Instead, deep-sea tailings placement (DSTP) has become more popular.

\section{Development and Recent Status of Deep-sea Tailings Placement}

Currently there are fifteen mining operations around the world using deep-sea tailings placement (Morello et al. 2016). Typically, the tailings are disposed below the surface euphotic zone $(\sim 50-100 \mathrm{~m})$ in areas with relatively low resource use by fisheries. In addition, current velocities at the prescribed sites are low which allows targeted tailings deposition, while minimizing resuspension and redeposition of the tailings (Ellis 2008). In general, the route to the target area of DSTP has a sufficient gradient to produce gravitational tailings flow. Flow routes and deposition sites with potential for quick sediment recovery to render biological and ecological recovery are also preferred.

While most current DSTP operations target the open deep ocean for tailings deposition, in Norway, deep fjords are the end zone (Vogt 2013; Ramirez-Llodra et al. 2015). The difference between these two options lies in unconfined (deep-sea) versus confined (fjords) disposal. In terms of economic returns, modern technologies make it possible to recover targeted elements/ metals in much lower concentrations than before; thus, there is now the potential to re-process old tailings. Unconfined disposal makes it impossible to exploit that potential, however. At the ecological level, depending on the volume of confined tailings deposited in the fjords, biological effects might not be very significant in the long term. For example, although original biota no longer exist near the Island Copper Mine in Vancouver Island, Canada, new species readily re-established after mine closure (Burd 2002; Ellis 2000). On the other hand, Ramirez-Llodra et al. (2015) fully described the variable effects of STD and DSTP on the submarine fauna in the fjords of Norway. The main impacts include higher sedimentation rate, toxicity, turbidity, and changes in sediment grain morphology.

In theory, the critical criteria for DSTP application are proximity to the coast, appropriate oceanographic features (e.g., suitable bathymetry), and relatively short pipelines from the mine to the discharge site. However, in practice, many currently operating mines use long pipelines to discharge tailings at a location that satisfies environmental regulations. For example, the Batu Hijau copper and gold mine in Indonesia discharges mine tailings $3.2 \mathrm{~km}$ from the shoreline and three mines in Papua New Guinea (Lihir Gold, Ramu Nickel Cobalt, and Simberi Gold) transport tailings via pipeline $1.5 \mathrm{~km}$, $450 \mathrm{~m}$, and $528 \mathrm{~m}$, respectively, to the shoreline (Vogt 2013) prior to oceanic disposal. Practically, future mines should use detailed bathymetric data to determine whether they are within close proximity to areas having sufficient depth and slope to facilitate DSTP. Note, however, it is highly unlikely that DSTP would be a feasible disposal option for mines located hundreds of kilometers from the coast (e.g., large parts of central Asia, Europe, and North America).

In order to understand the general applicability of DSTP, we constructed a bathymetric map of the seafloor globally. The aim was to identify broad areas that might be suitable for DSTP operations using a screening criterion of water depths greater than $1000 \mathrm{~m}$ within $1 \mathrm{~km}$ offshore. For the bathymetric data, we used the global 30 arc second GEBCO_2014 topographic grid: https://www.gebco.net/data_and_products/gridded_ bathymetry_data/.

The map was plotted in $\mathrm{R}$ ( $\mathrm{R}$ Core Team 2017) using the ggplot2 (Wickham 2009) marmap packages (Pante and Simon-Bouhet 2013) and was styled to illustrate global ocean depths and shallow waters $(<1000 \mathrm{~m})$ including a 1000-m contour around major land masses 
(light blue shading in Fig. 1). As can be seen, large areas of the world's coastline are unsuitable for DSTP operations owing to the shallowness of the coastal waters; only $0.14 \%$ of the world's coast has water of $1000 \mathrm{~m}$ depth or greater within $2 \mathrm{~km}$ of the coast. This includes most of North America, Europe, and southeastern Asia. Areas with deep waters close to shore include the northern coast of the Island of Papua New Guinea and a number of Pacific Islands. Thus, we suggest that DSTP would be a feasible option only in a limited number of locations.

Overall, with increasingly demanding international and national laws on waste disposal into the ocean, it is unlikely that DSTP will expand much in the future. Norway, Papua New Guinea, and Turkey will probably keep using the technique. In Greenland, there are no plans to use it. Chile may be the only country that will adopt DSTP for tailings disposal. Consequently, the total amount of tailings to be disposed in the ocean would not increase much from the current total of roughly 200 kilotonnes/day from six operating mines (Table 1) based on the estimation of Morello et al. (2016). This total is equivalent to 80 megatonnes per year or 4 gigatonnes in 50 years if all mines remain in operation at current production. This number is relatively small when compared with an estimated global annual load of river-borne sediments to the world's oceans of 20 gigatonnes/year (Syvitski et al. 2003).
In addition, this amount of tailings discharged to the deep oceans is unlikely to exceed the natural deep-sea mineral deposits associated with hydrothermal vein systems in mid-ocean ridges. These ridges are highly enriched in metals. For example, one of the twelve prospective deep-sea mining sites found off Papua New Guinea has the potential to produce 1.3 million tonnes of ore with $7.5 \% \mathrm{Cu}$ and $7.2 \mathrm{~g}$ per tonne of $\mathrm{Au}$ (Earth Magazine 2014).

\section{On-land Tailings Disposal}

Over 99\% of metal mines dispose tailings on land (Vogt 2014). Depending on the availability of water and extant regulatory systems, these tailings are stored either underwater or subaerially. Reactive tailings (i.e., with high acid rock drainage/metal leaching (ARD/ML) potential) are stored underwater either in engineered impoundments or less commonly in low-production natural lakes or artificial lakes. Often, an engineered tailings pond or impoundment contains a dam to hold water at a reasonable depth to deplete oxygen that supports sulfide oxidation. Typically, less reactive tailings are located elsewhere at mine sites under dry covers and overlain with local vegetation upon mine closure. Regardless of reactivity, in some cases, tailings mixed with cement are used to backfill underground workings. Recently,

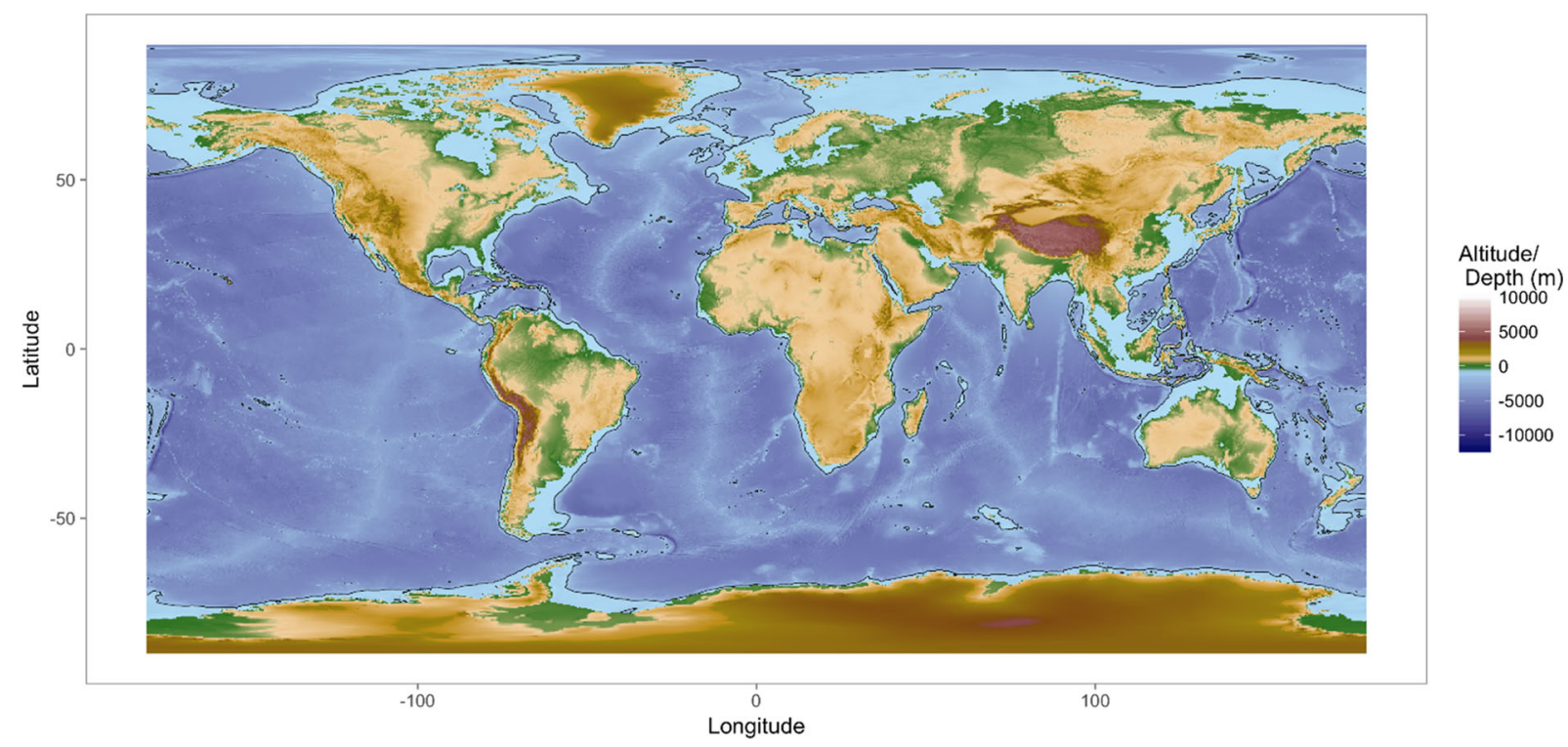

Fig. 1 Bathymetric map of the world. The pale blue shows areas of seabed where the depth is between 0 and $1000 \mathrm{~m}$; the black line represents the 1000-m-depth contour. Bathymetric data were retrieved from the NOAA server (Amante and Eakins 2009) 
Table 1 Quantities of tailings discharged into the marine environment at current operating mines

\begin{tabular}{|c|c|}
\hline Mines, location, and release depth & Tonnes/day \\
\hline $\begin{array}{l}\text { Batu Hijau, } \mathrm{Cu} / \mathrm{Au} \text {, Indonesia, } \\
\text { discharged at } 108 \mathrm{~m} \text { depth }\end{array}$ & 160,000 \\
\hline $\begin{array}{l}\text { Cayeli Bakir, } \mathrm{Cu} / \mathrm{Zn} / \mathrm{Pb} \text {, Turkey, } \\
\text { discharged at } 275 \mathrm{~m} \text { depth }\end{array}$ & 12,000 \\
\hline $\begin{array}{l}\text { Gardanne, Al, France, } \\
\text { discharged at } 275 \mathrm{~m} \text { depth }\end{array}$ & 4000 \\
\hline $\begin{array}{l}\text { Huasco iron, Fe, Chile, } \\
\text { discharged at } 35 \mathrm{~m} \text { depth }\end{array}$ & 3000 \\
\hline $\begin{array}{l}\text { Lihir, Au, Papua New Guinea, } \\
115 \mathrm{~m} \text { discharge depth }\end{array}$ & 8000 \\
\hline $\begin{array}{l}\text { Simberi oxide, } \mathrm{Au} / \mathrm{Ag}, \\
\quad \text { Papua New Guinea, at } 130 \mathrm{~m} \text { depth }\end{array}$ & 9040 \\
\hline Sydvaranger, Fe, Norway, at $28 \mathrm{~m}$ depth & 10,960 \\
\hline $\begin{array}{l}\text { Ramu, Co/Ni, } \\
\quad \text { Papua New Guinea, at } 150 \mathrm{~m} \text { depth }\end{array}$ & 13,700 \\
\hline Total & 220,700 \\
\hline $\operatorname{DSTP}(>100 \mathrm{~m})$ & 206,740 \\
\hline $\operatorname{STD}(<100 \mathrm{~m})$ & 13,960 \\
\hline
\end{tabular}

particularly with uranium mining in Saskatchewan, Canada, tailings are stored in mined-out open pits with special designs such that contaminant transport is largely controlled. However, the extent of long-term contaminant transport in decreased concentrations in the groundwater system remains unknown.

The size of tailings retention facilities varies greatly, but a typical tailings dam is likely to have a surface area of between 1 and $10 \mathrm{~km}^{2}$. This is a far smaller footprint than DSTP where tailings deposition is usually unconfined and only restricted by the local bathymetric features of the ocean floor (e.g., submarine canyons).

Worldwide, discharges from tailings impoundments are subject to special regulations to protect the surrounding and downstream environments. To meet these requirements, most mines tend to reduce the amount of water discharged from the tailings impoundment, often treating it before discharge. The most frequent methods used include as follows: (a) diversion of natural water to prohibit ingress to the tailings impoundment; and (b) reuse of some of the tailings water for ore processing. In addition, methods for co-disposal of tailings and waste rock to generate more stable products and reduce conventional slurry tailings discharged subaerially are currently under development in the mining industry (Mining Magazine 2017).

In Canada, the overall good performance of tailings disposal in metal mines is evident from the compliance with the Metal Mining Effluent Regulations (MMER) as reported by Environment Canada (2011). Between 2003 and 2010, the average compliance rate was over $99 \%$ across the country. The performance variation relative to predictions among different metal mines indicates that non-compliance is greatest among base metal and iron ore mines (Fig. 2). Four factors that appear to control the performance include as follows: (a) mine type; (b) mining, processing, and waste management methods; (c) mining history; and (d) mine permit stipulations and extent of oversight. These lead to the importance of using geoenvironmental ore deposit models in mine planning prior to operation, as discussed below.
Fig. 2 Relative performance of metal mines in Canada in 20032010 based on data from Environment Canada (2011)

\section{MMER Non-Compliance by Sector}

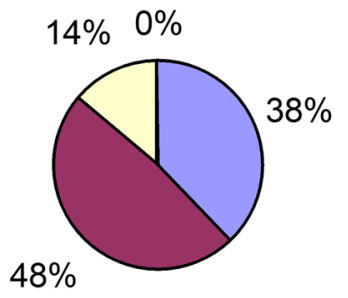

Base metals $\square$ Iron ore $\square$ Precious metals $\square$ Uranium 


\section{Discussion}

Based on the information provided above, a few issues warrant further discussion. These include the following: (a) advantages and disadvantages of submarine tailings disposal versus on-land storage; (b) international versus national laws on submarine tailings disposal and public opinion on the issue; (c) implications of larger mines now and in the future; and (d) importance of geoenvironmental ore deposit models. The key points are as follows.

\subsection{Advantages and Disadvantages of Submarine Tailings Disposal Versus On-land Storage}

While the practice of submarine tailings disposal is significantly less common than that of on-land disposal worldwide, it still occurs in coastal and island countries such as Norway and Papua New Guinea (PNG). As summarized in Table 2, there are four main reasons for this:

a) Lack of sufficient land for mine waste disposal for increasingly bigger mines.

b) DSTP permits better land use and increased income for local population as well as national and local governments. c) There is significantly less expensive for the mining industry both during operation and after mine closure.

d) There is less risk in seismically active, highprecipitation regions (e.g., PNG is prone to earthquakes and has very high rainfall, thus increasing the risk of dam collapse).

Overall, the choice of DSTP or on-land tailings disposal will largely depend on local settings. Moreover, there can be geochemical advantages: DSTP is an effective way of dealing with acid generating materials. Biological concerns remain, however (e.g., Sondergaard et al. 2011). Although overall the ocean has a lower biomass than the continents, it potentially has a high species diversity and ecosystem value (e.g., coral reefs). The choice of DSTP locations must take potential impacts on such ecosystems into account.

In contrast, the main practice for disposal of mine tailings on land is to contain them in confined areas; such approaches are continually subject to improvement. The EcoTails technology currently under development by Goldcorp Inc. (Mining Magazine 2017) is a good example. In essence, blended filtered tailings and waste rock in transit create a product that reduces oxygen flow and yields improved shear strength and better physical stability. This eliminates the need to keep

Table 2 Advantages and disadvantages of DSTP versus on-land tailings disposal

\begin{tabular}{|c|c|c|}
\hline $\begin{array}{l}\text { Disposal } \\
\text { method }\end{array}$ & DSTP & On-land \\
\hline Advantages & $\begin{array}{l}\text { - Small terrestrial footprint } \\
\text { - Low running costs } \\
\text { - ARD not an issue } \\
\text { - Minimal post-closure treatment and } \\
\text { maintenance required }\end{array}$ & $\begin{array}{l}\text { - Generally applicable at most mine sites (with proper design and } \\
\text { operation) } \\
\text { - Abundant supply of experienced personnel } \\
\text { - Opportunity for tailings re-use } \\
\text { - Tailings confined to a known spatial area }\end{array}$ \\
\hline Disadvantages & $\begin{array}{l}\text { - Burial and smothering of benthic fauna } \\
\text { - Remobilization of tailings and release of } \\
\text { contaminants } \\
\text { - Water column impacts of secondary tailings plumes } \\
\text { which peel off from the main density current } \\
\text { - Impacts on the deep oceans are largely unknown } \\
\text { - No possibility of tailings re-use } \\
\text { - Restricted to mines located close to coasts } \\
\text { - Cost of pre-mining environmental investigations } \\
\text { and their duration } \\
\text { - Large tailings footprint } \\
\text { - Potential contamination of marine foodwebs } \\
\text { which may affect coastal communities }\end{array}$ & $\begin{array}{l}\text { - Land required - especially for low grade ores } \\
\text { - Risk of catastrophic failure } \\
\text { - Long term ARD management may be necessary } \\
\text { - Post-mine maintenance and monitoring necessary } \\
\text { - Likely strict controls on water discharge requiring some water } \\
\text { treatment } \\
\text { - Cost of building and maintaining tailings impoundment } \\
\text { infrastructure }\end{array}$ \\
\hline
\end{tabular}


conventional slurry tailings underwater in a pond. With traditional tailings management, serious mistakes can occur even in operating mines. The failures of the tailings dam in 2014 at the Mount Polley Mine in British Columbia, Canada (Province of British Columbia 2015), and in 2015 at the Samarco Mine in Brazil (The Guardian 2016) are examples. In other words, on-land tailings disposal is not without risk. Another mining alternative under consideration is in situ recovery (Seredkin et al. 2016) that involves metal leaching underground without producing any tailings on land.

\subsection{Regulations and Public Opinion}

For DSTP to be possible, a mine must be located near the sea in a country with steep offshore bathymetry and favorable ocean currents. Currently, only fifteen mines located in six countries (Chile, France, Greece, Indonesia, Norway, and Papua New Guinea) use DSTP; five have existing legal frameworks for such discharges while in Chile, no formal laws exist yet (Morello et al. 2016). Peru, a primary host of the 2015 international workshop in Lima on impacts of mine tailings in the marine environment (GESAMP 2016), is also interested in using STD. In Canada, the Metal Mining Effluent Regulations enforced since 2002 practically bans all submarine tailings disposal. In the USA, the Effluent Guidelines and Standards introduced by the Environmental Protection Agency in 2001 is a similar regulation that prohibits STD. Thus, although there are many mining operations and prospects in the northern, eastern, and western coastal regions of Canada and several in Alaska, USA, submarine tailings disposal is no longer practiced in North America. Internationally, the 1996 updated version of the "Protocol to the Convention on the Prevention of Marine Pollution by Dumping of Waste and Other Matter, 1972 (London Protocol)" is the active law on dumping industrial waste into the ocean. However, discharges of mine tailings into the sea are apparently not "dumping" and thus "not under the direct jurisdiction of the London Convention or Protocol" (GESAMP 2016).

Public views on mining are often the result of old experiences and new objectives. For example, many older Indigenous people in Canada will not accept uranium mining in the North due to environmental and human impacts of former mines, which are still undergoing reclamation. However, the younger generation has fewer objections due to potential job opportunities and better mining practices. On the other hand, uranium exploration is not welcome in some provinces (such as British Columbia) where the population has a high degree of environmental awareness. With respect to DSTP, although it is legal in Norway, there is strong opposition by local environmentalists (e.g., Friends of the Earth Norway 2015).

\subsection{Implications of Larger Mines Today and in the Future}

As metal mining is producing more tailings and waste rock with time, practical mine waste disposal methods must also advance. Traditionally, sulfiderich acid-generating tailings are stored underwater and the non-sulfide tailings confined on land. Increasingly, tailings placement in mined-out open pits is applied. With increasing mine waste production from low-grade ores, the EcoTails technology under development by Goldcorp Inc. (Mining Magazine 2017) appears to be an attractive option. The advantages and disadvantages of underground versus open-pit mining should be re-examined at all stages of mining. The switch from open pit to underground mining of some orebodies at the Raglan nickel and copper mine in northern Quebec (Canada) shortly after the start of operation is a good example of such an action (Bekkers 2003).

For mines operating near the ocean, DSTP may be an option if the local settings are suitable. However, to improve environmental performance, perhaps only chemically treated tailings (e.g., desulfurized) should be disposed into the ocean. This would reduce potentially hazardous effects on the local biota even if some secondary plumes develop along during the downward flow. While DSTP can undergo incremental improvements, the mining industry still faces the challenge of waste rock disposal and mitigation of ARD/ML for sulfide-rich geological materials. Where shallow shores are also present, waste rocks could be disposed below the low-tide depth, with reduced oxygen content for sulfide oxidation. Although it is unrelated to mining, the submerging of acid generating sulfide-rich rock resulting from building and road construction in Halifax (Nova Scotia, Canada) in a designated location in the harbor is a good example of such a practice. 


\subsection{Importance of Geoenvironmental Ore Deposit Models}

Ore deposits have a type-specific environmental behavior controlled by geology, mineralogy, and local setting (Seal II and Folsey 2002; Kwong 2003; Kwong 2009; Kwong 2011). Given an ore deposit of specific geology, mineralogy, and setting, there are limited ways to mine it economically, extract the commodities of interest, and manage the wastes generated. The environmental outcomes can differ drastically depending on the methods used to exploit the identified resources. Kwong (2011) has described two such examples. Thus, it is advantageous to conceive and develop an appropriate geoenvironmental ore deposit model (Fig. 3) prior to setting up a mining operation. In its simplest form, a comprehensive environmental ore deposit model for a specific ore type is composed of a compilation of the following essential ingredients:

- Deposit geology as well as structural controls of mineralization and alteration

- Deposit mineralogy including mineral zoning and alteration patterns

- Applicable mining methods and their environmental implications

- Available milling practices and their potential effects on mine effluent quality

- Mine waste management alternatives and their potential environmental impacts

- Identified and/or potential contamination problems

Similar to traditional ore deposit models, the underlying principle of comprehensive environmental ore deposit models is to document and utilize past experience to guide new activities. The essential functions of such a model include the following:

a) Facilitate communication and engagement among all departments and stakeholders

b) Assist in adaptive planning and mine management

c) Allow field geologists to look at potential environmental issues and start to develop solutions during exploration

d) Aid with making development decisions with no more stepwise mining

e) Accelerate permitting

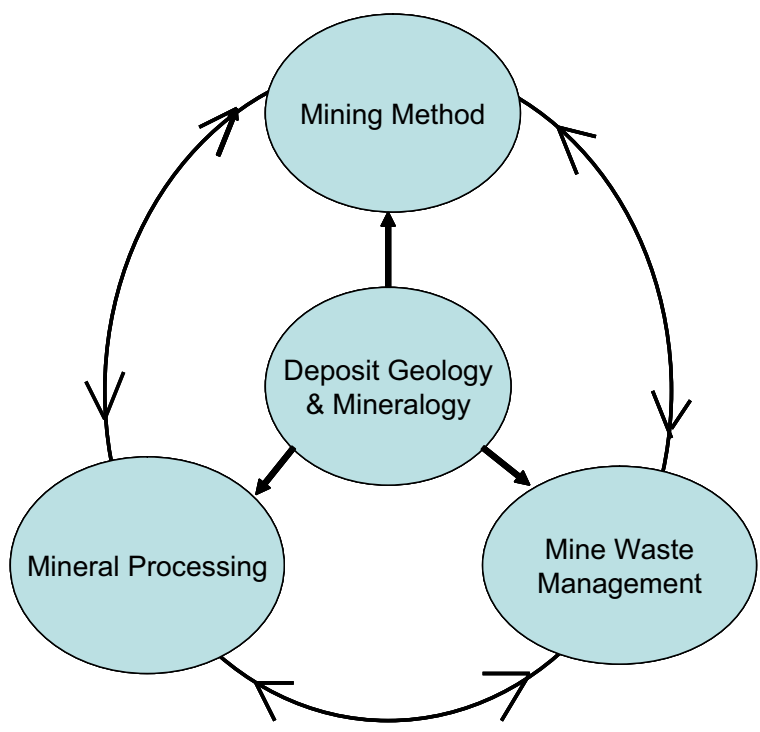

Fig. 3 Components of a geoenvironmental ore deposit model and their inter-relationships

f) Make appropriate changes in mining, processing, and mine waste management to overcome changing conditions when required

Such models apply not only to mines with all facilities located on land but also for mines using DSTP. The only complication is that, in the latter case, oceanic conditions become an unavoidable consideration during mine planning. Additional data may be necessary.

\section{Conclusion}

Although DSTP could be locally practical, it has poorly defined environmental impacts. Whether on-land storage or deep-sea placement is preferred for tailings disposal depends on the local settings. Overall, global impacts of DSTP with respect to sediment load to the ocean are relatively small compared with riverine discharges of sediments by anthropogenic activities. Ultimately, national and local laws dictate whether DSTP is a waste disposal option worthy of consideration or not.

Acknowledgments CanmetMINING, Natural Resources Canada, and CSIRO, Australia, have kindly supported this international project. Charlene Hogan of CanmetMINING provided key internal review. Comments from an anonymous reviewer have greatly improved the manuscript. 
Open Access This article is distributed under the terms of the Creative Commons Attribution 4.0 International License (http:// creativecommons.org/licenses/by/4.0/), which permits unrestricted use, distribution, and reproduction in any medium, provided you give appropriate credit to the original author(s) and the source, provide a link to the Creative Commons license, and indicate if changes were made.

\section{References}

Amante, C., \& Eakins, B. W. (2009). ETOPO1 1 Arc-Minute Global Relief Model: procedures, data sources and analysis. NOAA Technical Memorandum NESDIS, NGDC-24, 19 pp http://www.ngdc.noaa.gov/mgg/global/relief/ETOPO1 /docs/ETOPO1.pdf.

Asmund, G., Johansen, P., \& Fallis, B. W. (1991). Disposal of mine wastes containing $\mathrm{Pb}$ and $\mathrm{Zn}$ near the ocean: an assessment of associated environmental implications in the Arctic. Chemistry and Ecology, 5, 1-15.

Bekkers, J.G.L. (2003). Open pit reclamation and waste rock strategy at Raglan. In: Mining in the Arctic (edited by J.E. Udd and G. Bekkers), Proceedings of the 7th International Symposium on Mining in the Arctic, Iqaluit/Nunavut/ Canada/March 30-April 1 2003, Canadian Institute of Mining, Metallurgy and Petroleum, Montreal, Quebec, 2003, pp.127-138.

Berkun, M. (2005). Submarine tailings placement by a copper mine in the deep anoxic zone of the Black Sea. Water Research, 39, 5005-5016.

Bradford, R. W., Young, J. W., Lyne, V. D., Lamb, T. D., \& Haskard, K. A. (1999). Has jarosite dumping at a deepwater site off eastern Tasmania, Australia, had a measurable effect on the midwater zooplankton communities? Water, Air, and Soil Pollution, 116, 639-663.

Burd, B. J. (2002). Evaluation of mine tailings effects on a benthic marine in fauna community over 29 years. Marine Environment Research, 53, 481-519.

Burd, B., Macdonald, R., \& Boyd, J. (2000). Punctuated recovery of sediments and benthic infauna: a 19-year study of tailings deposition in a British Columbia fjord. Marine Environmental Research, 49, 145-175.

Castilla, J. C., \& Nealler, E. (1978). Marine environmental impact due to mining activities of El Salvador copper mine, Chile. Marine Pollution Bulletin, 9, 67-70.

Dold, B. (2006). Element flows associated with marine shore mine tailings deposits. Environmental Science \& Technology, 40, $752-758$.

Dold, B. (2014). Submarine tailings disposal (STD) - a review. Minerals, 4, 642-666.

Drysdale, K. (1990). Geochemistry of a buried marine mine tailings deposit, Howe Sound. British Columbia. MSc thesis: University of British Columbia, Vancouver.

Earth Magazine. (2014). Staking a claim: deep-sea mining nears fruition. Earth Magazine, (June 2014), 7 pp.

Ellis, D. V. (2000). Effect of mine tailings on the biodiversity of the seabed: example of the Island Copper Mine. Canada. Seas of the millennium - an environmental evaluation, 3, 235-246.

Ellis, D. (2008). The role of deep submarine tailings placement (STP) in the migration of marine pollution for coastal and island mines. In: T.N. Hofer (Ed) Marine pollution: new research, pp.23-51.

Ellis, D., \& Ellis, K. (1994). Very deep STD. Marine Pollution Bulletin, 28, 472-476.

Ellis, D. V., \& Hoover, P. M. (1990). Benthos on tailings beds from an abandoned coastal mine. Marine Pollution Bulletin, 21(10), 477-480.

Ellis, D. V., \& Poling, G. W. (Eds.). (1995). Special issue: submarine tailings disposal. Marine Georesources and Geotechnology, 13(1/2), 1-233.

Ellis, D. V., Pedersen, T. F., Poling, G. W., Pelletier, C., \& Horne, I. (1995). Review of 23 years of STD: Island Copper Mine, Canada. Marine Georesources and Geotechnology, 13, 5999.

Environment Canada (2011). Summary review of performance of metal mines subject to the Metal Mining Effluent Regulations 2003-2010

EVS Environmental Consultants (1997). Summary and overview of environmental effects of the Anaconda Britannia Mine on juvenile salmonids and the marine environment in Howe Sound, BC. Prepared for Environment Canada, 78 pp.

Friends of the Earth Norway (Naturvernforbundet). (2015). Submarine tailings disposal violates the water framework directive (33 pp). The Norwegian: Society for the Conservation of Nature/Friends of the Earth Norway.

Ganguli, R., Wilson, T. E., \& Bandopadhyay, S. (2002). An expert system for marine disposal of tailings. Mining Engineering, 54, 29-34.

GESAMP (Joint Group of Experts on the Scientific Aspects of Marine Environment Protection) (2016). GESAMP Reports \& Studies No.94 - Proceedings of the GESAMP International Workshop on the Impacts of Mine Tailings in the Marine Environment, June 10-12, 2015, Lima, Peru, 83 pp.

Kwong, Y. T. J. (2003). Comprehensive environmental ore deposit models as an aid for sustainable development. Journal of Exploration and Mining Geology, 12(1-4), 31-36.

Kwong, Y.T.J. (2009). Practical applications of environmental ore deposit models in mine development with a SEDEX example. In: J. Wiertz and C.J. Moran (Eds) Proceedings of the First International Seminar on Environmental Issues in the Mining Industry, 30 September - 2 October, Santiago, 2009 Chile, 8 pp.

Kwong, Y.T.J. (2011). Role of environmental ore deposit models in resources development. In: Proceedings of the Eighth International Mining Geology Conference, Queenstown, New Zealand, 22-24 August 2011, The Australian Institute of Mining and Metallurgy Publication Series No 8/2011, pp.437-441.

Kwong, Y. T. J., \& Hynes, T. P. (2003). Benefits and risks of submarine tailings disposal - lessons learnt from two historic mine sites in Newfoundland and other Canadian case studies. In Proceedings of the 6th International Conference on Acid Rock Drainage, Cairns, Australia, 14-17 July 2003. The Australasian Institute of Mining and Metallurgy, Carlton South (pp. 719-724).

Larsen, T. S., Kristensen, J. A., Asmund, G., \& Bjerregaard, P. (2001). Lead and zinc in sediments and biota from Maarmorilik, West Greenland: an assessment of the environmental impact of mining waste on an Arctic fjord system. Environmental Pollution, 114, 275-283. 
Lee, M. R., Correa, J. A., \& Zhang, H. (2002). Effective metal concentrations in pore water and seawater labile metal concentrations associated with copper-mine tailings disposal into the coastal waters of the Atacama region of northern Chile. Marine Geosciences and Geotechnology, 19, 51-63.

Loring, D. H., \& Asmund, G. (1989). Heavy metal contamination of a Greenland fjord system by mine wastes. Environmental Geology, 14, 61-71.

Mining Magazine (2017). Goldcorp trials new EcoTails technology, 30 March 2017 (Accessible through Google with the same title), http://www.miningmagazine.com/future-ofmining/future-of-mining-sustainability/goldcorp-trials-newecotails-technology/

Morello, E. B., Haywood, M. D. E., Brewer, D. T., Apte, S. C., Asmund, G., Kwong, Y. T. J., \& Dennis, D. (2016). The ecological impacts of submarine tailings placement. In: R.N. Hughes, D.J. Hughes, I.P. Smith and A.C. Dale (Editors) Oceanography and marine biology: an annual review, 54, 315-366.

Pante, E., \& Simon-Bouhet, B. (2013). marmap: a package for importing, plotting and analyzing bathymetric and topographic data in R. PLoS One 8(9): e73051. doi:https://doi. org/10.1371/journal.pone.0073051

Pena, J. A., Mantecea, J. L., Martinez-Pagan, P., \& Teixido, T. (2013). Magnetic gradient map of the mine tailings in Portman Bay (Murcia, Spain) and its contribution to the understanding of the bay infilling process. Journal of Applied Geophysics, 95, 115-120.

Perner, K., Leipe, T., Dellwig, O., Kuijpers, A., \& Mikkelsen, N. (2010). Contamination of arctic Fjord sediments by $\mathrm{Pb}-\mathrm{Zn}$ mining at Maarmorilik in central West Greenland. Marine Pollution Bulletin, 60, 1065-1073.

Plumlee, G. S., \& Logsdon, M. J. (1999). An earth-system science toolkit for environmentally friendly mineral resources development. In: G.S. Plumlee and M.J. Logsdon (Volume editors) The environmental geochemistry of mineral deposits, part a: processes, techniques, and health issues, Reviews in Economic Geology Volume 6A (pp. 1-27). Inc: Society of Economic Geologists.

Poling, G.W. (2002). An introduction to deep-sea tailings placement. In G.W. Poling et al. (eds): Underwater tailings placement at island copper mine: a success story, Littleton, Colorado: Society for Mining, Metallurgy, and Exploration, $1-15$.

Province of British Columbia. (2015). Report on Mount Polley tailings storage facility breach. Independent Expert Engineering and Review Panel, January, 30, 2015, 147 pp.

Ramirez-Llodra, E., Trannum, H. C., Evenset, A., Levin, L. A., Andersson, M., Finne, T. E., Hilario, A., Flem, B.,
Christensen, G., Schaanning, M., \& Vanreusel, A. (2015). Submarine and deep-sea mine tailing placement: a review of current practices, environmental issues, natural analogs and knowledge gaps in Norway and internationally. Marine Pollution Bulletin, 97, 13-35.

Seal II, R.R., \& Folsey, N.K. (Editors, 2002). Progress on geoenvironmental models for selected mineral deposit types, U.S. Geological Survey Open-file Report 02-195, 215 pp.

Seredkin, M., Zabolotsky, A., \& Jeffress, G. (2016). In situ recovery, an alternative to conventional efforts of mining: exploration, resource estimation, environmental issues, project evaluation and economics. Ore Geology Reviews, 79, 500514.

Sondergaard, J., Asmund, G., Johansen, P., \& Riget, F. (2011). Long-term response of an arctic fiord system to lead-zinc mining and submarine disposal of mine waste (Maarmorilik, West Greenland). Marine Environmental Research, 71, 331341.

Syvitski, J. P. M., \& Macdonald, R. D. (1982). Sediment character and provenance in a complex fjord, Howe Sound, British Columbia. Canadian Journal of Earth Sciences, 19, 10251044.

Syvitski, J. P. M., Peckham, S. D., Hilberman, R., \& Mulder, T. (2003). Predicting the terrestrial flux of sediment to the global ocean: a planetary perspective. Sedimentary Geology, 162, $5-24$.

The Guardian (2016). Samarco dam collapse: one year on from Brazil's worst environmental disaster, http://theguardian. com/sustainable-business/2016/oct/15/samarco-damcollapse-brazil-worst-environmental-disaster-bhp-billitonvale-mining, $5 \mathrm{pp}$.

Vogt, C. (2013). International assessment of marine and riverine disposal of mine tailings (full report), November 2013, 138 pp, available at www.CraigVogt.com (A final report adopted by the International Maritime Organization, London Convention/Protocol, 18 October 2013.)

Vogt, C. (2014). International assessment of marine and riverine disposal of mine tailings. In: Impact assessment for social and economic development, Proceedings of the 34th Annual Conference of the International Association for Impact Assessment, 8-11 April 2014, Chile, 6 pp.

Wickham, H. (2009). ggplot2: elegant graphics for data analysis. Springer-Verlag New York.

Publisher's Note Springer Nature remains neutral with regard to jurisdictional claims in published maps and institutional affiliations. 